\title{
PROBLEMATIKA PENDIDIKAN MORAL DI SEKOLAH dan UPAYA PEMECAHANNYA
}

Nanang Abdillah

STAI Al Azhar, Menganti Gresik_Jl. Raya Menganti Krajan No 447

Gresik fulcom@yahoo.com

\section{ABSTRACT}

School is an institution that tries to process input in the form of students into outputs that not only master knowledge from one domain, but from the three domains, namely cognitive, effective and psychomotor comprehensively including moral education. But in reality, it is often found deviations of student behavior, which in turn emerge moral degradation in students. Schools will have more meaning if they have implemented moral education in students in totality.

Keywords: Education, Moral, Indonesia.

\section{ABSTRAK}

Sekolah merupakan sebuah lembaga yang berusaha memproses input yang berupa siswa menjadi output yang tidak hanya menguasai pengetahuan dari salah satu ranah saja, melainkan dari ketiga ranahnya yaitu kognitif, efektif dan psikomotorik secara komprehensif termasuk di dalamnya pendidikan moral. Namun kenyataannya, sering dijumpai penyimpangan perilaku siswa, yang pada akhirnya muncul adanya degradasi moral pada siswa. Sekolah akan bermakna lebih jika sudah menerapkan pendidikan moral pada siswa secara totalitas.

Kata Kunci: Pendidikan, Moral, Indonesia.

Program Studi Pendidikan Guru Madrasah Ibtidaiyah

STAI Al-Azhar Menganti Gresik, Indonesia

\section{Pendahuluan}

Keberadaan moral bagi kehidupan seseorang (pelajar) sangat penting dalam keluarga dan masyarakat. Moral pelajar yang lebih baik dalam kehidupan. Dan sebaliknya, moral pelajar yang tidak baik akan mengakibatkan suatu interaksi yang tidak harmonis dalam masyarakat yang selanjutnya akan memunculkan kegelisahan sosial. (H.A.R. Tilaar, 1999) mengatakan bahwa "degradasi moral telah menggejala dalam kehidupan masyarakat modern dewasa ini, demikian halnya dengan para pelajar dan mahasiswa. Banyak kalangan muda atau pelajar yang melakukan tindakan-tindakan yang tidak bermoral".

Dalam pandangan sarjana barat seperti Pane W. Tailor, melihat moral sebagai suatu set peraturan atau standar sosial yang mengatur tingkah laku orang-orang di dalam suatu kebudayaan (Pane, 1967). Berdasarkan hal tersebut, berarti moral itu berkaitan dengan prinsip baik dan buruk yang diwujudkan dalam perilaku sebagai gambaran dari keadaan jiwa, tabiat seseorang, dan komponen-komponen moral. Setidaknya terdiri atas pertimbangan moral(keadaan batini)dan perilaku moral (keadaan lahiri). 
Moral manusia menurut pandangan al-Ghozali dan Ibnu Miskaway maupun Piaget dan Kohlberg dapat dikembangkan sampai mencapai tingkat kesempurnaan (Miskaway, 1996). Untuk membentuk moral seseorang menjadi baik diperlukan serangkaian usaha-usaha konkrit, dan peran ini diambil oleh lembaga pendidikan. Dalam diri manusia terdapat dua potensi, baik dan buruk sama-sama baik, bahkan potensi buruk itu cenderung lebih kuat jika melihat urutan penyebutan potensi tersebut dalam Al-Qur'an (Q.S. 91:8), yang artinya: "Maka mengilhamkan kepada jiwa itu(jalan)kefasikan dan ketaqwaan-Nya". Ini berarti jika manusia tidak mendapatkan pendidikan(moral), maka ia cenderung akan mengikuti memenangkan potensi buruk. Oleh karena itu diperlukan pendidikan moral.

\section{Hasil Penelitian}

\section{Pendidikan Moral}

Pendidikan moral adalah penanaman, pengembangan dan pembentukan akhlak yang mulia dalam diri anak. Pendidikan moral harus merupakan satu program atau pelajaran khusus, akan tetapi merupakan suatu dimensi dari seluruh usaha Pendidikan (Satra, 2000). Sedangkan menurut Nasikh Ulwan mengemukakan bahwa "Pendidikan moral adalah sendi moral, keutamaan tingkah laku yang wajib dilakukan oleh anak didik, diusahakan dan dibiasakan sejak kecil hingga dewasa". (Ulwan, 1990). Ini berarti bahwa moral seseorang itu dapat dipupuk dan dapat dikembangkan menuju tingkat perkembangan yang sempurna dalam suatu proses pendidikan.

Para psikolog seperti Pieget dan Kohlberg memandang bahwa moral seseorang itu mengalami perkembangan dalam tahap-tahap operasional yang ciri-cirinya: terjadi perubahan secara bertahap kepemilikan moral. Tahap ketiga: Format operasional yang ciri-cirinya: memperimbangkan tujuantujuan perilaku moral, menyadari bahwa aturan moral adalah kesempatan tradisi yang berubah (Muhibbin, 1995). Sedangkan menurut Kohlberg, ia sempurnakan menjadi enam tahap dalam tiga tingkat yaitu:

1. Tingkat pertama, moralitas pra-konvensional yang terdiri dari tahap satu memperhatikan pemuasan kebutuhan.

2. Tingkat kedua, moralitas konvensional yang terdiri atas tahap tiga, yaitu memperhatikan citra anak baik, dan tahap empat, yaitu memperhatikan hukum dan peraturan.

3. Tingkat ketiga, moralitas pasca konvensional, terdiri dari tahapan lima yaitu, memperhatikan hak perseorangan, dan tahap enam, yaitu memperhatikan prinsip-prinsip universal (Elfin, 1983). 
Tugas pendidikan adalah mem bantu anak mencapai tahap perkembangan moral yang tinggi (kesempurnaan moral). Dalam pandangan al-Ghozali dan Ibn Miskaway, tugas pendidikan adalah membentuk anak mencapai kesempurnaan jiwa, dalam artian bahwa, tindakan moral yang ia lakukan sudah menyatu dalam dirinya sehingga tanpa melalui proses berfikir (Miskaway, 1934). Walaupun keduanya tidak menyebutkan tahap perkembangan secara rinci. Adapun aspek yang dibutuhkan dalam mencapai perkembangan moral tersebut adalah prinsip pembiasan (condisioning) dan peniruan (imitation) yang mengarah pada terjadinya modeling. Pandangan ini adalah pandangan menurut alGhozali dan Ibn Miskaway begitu juga dengan A. Bandura, perkembangan moral tersebut berbeda dengan pandangan menurut Piaget dan Kohlberg (aliran moral relatism) yang lebih menekankan adanya keterkaitan struktur kognisi dalam perkembangan moral.

Aplikasinya dalam dunia pendidikan dari kedua pandangan tersebut adalah diperlukan adanya condisioning dalam mengembangkan perilaku moral seseorang. Dalam hal ini faktor pemberian reinforcement (reward dan punishment) memegang peran yang penting untuk membiasakan anak melakukan tindakan moral yang baik. Dalam pemberian reinforcement terhadap perilaku yang baik, komentar-komentar yang disampaikan guru merupakan faktor penting untuk proses internalisasi atau penghayatan siswa terhadap standar moral. Faktor lain adalah pemberian teladan atau contoh dari guru dari tindakan-tindakan yang baik. Kemudian diperlukan adanya penjelasan-penjelasan terhadap pertimbangan moral (alasan-alasan melakukan komentar-komentar yang disampaikan guru merupakan faktor penting untuk proses internalisasi atau penghayatan siswa terhadap standar moral). Faktor lain adalah pemberian teladan atu contoh dari guru dari tindakan-tindakan yang baik. Kemudian diperlukan adanya penjelasan-penjelasan terhadap pertimbangan moral(alasan-alasan melakukan tindakan), sehingga dapat dicapai perkembangan moral pada tingkat yang tertinggi.

Dari kedua pandangan, dapat dikatakan bahwa pendidikan di satu pihak bertujuan memupuk kemampuan anak agar ia mampu mempertimbangkan moral serta dapat memberikan justifikasi moral pada "tahapan pemikiran moral yang dianggap lebih tinggi dan lebih diharapkan". Apabila individu yang bersangkutan dianggap telah siap bergerak setapak demi setapak melalui urutan tahapan yang telah ditentukan, maka perhatian selanjutnya ditunjukkan pada cara berfikir serta sistem nilai yang diharapkan tidak lagi dilakukan anak dan didorong mampu melakukan pertimbangan moral baik untuk dirinya maupun untuk orang lain, sambil mengokohkan kepercayaan akan keutamaan moral yang diajarkan kemudian.

Beberapa penelitian telah menunjukkan bahwa seorang dewasa yang secara langsung kepada anak, suatu pertimbangan yang didasarkan pada tujuan yang benar dengan menerangkan alasannya, ternyata berjalan efektif (William, 1992). Dari hal di atas dapat dikatakan bahwa dalam pendidikan moral, faktor-faktor yang memegang peranan penting antara lain: 
1. Pembiasan(condisioning)

yang didalamnya diperlukan adanya reinforcement, baik berupa reward maupun punishment terhadap perilaku moral anak jika anak melakukan tindakan moral yang diharapkan(baik), maka diberi pujian(hadiah). Jika melakukan tindakan moral yang tidak di harapkan(buruk), maka diberi hukuman. Dari adanya pembiasan ini internalisasi nilai moral yang diajarkan akan dapat diwujudkan dalam diri anak. Anak akan menyadari perilaku moral mana yang harus di amalkan dalam kehidupan dan mana yang harus dihindari. Dari adanya pembiasan tersebut, perilaku moral yang diajarkan akan menjadi suatu kebiasaan yang selanjutnya akan membentuk suatu watak atau tabiat anak. Menjadi contoh bagi siswanya untuk memberikan contoh/teladan perilaku-perilaku moral yang baik terhadap anak didik.

2. Pengembangan berfikir kritis terhadap alasan dan tujuan perilaku moral

yang didalamnya diperlukan adanya diskusi dan pembahasan intensif serta penjelasan terhadap pertimbangan moral(alasan melakukan suatu perilaku moral), serta tujuan dan akibat dari tindakan moral. Dari adanya pemikiran kritis akan dimungkinkan mengembangkan perilaku moral anak dari suatu perilaku moral yang hanya berpusat untuk dirinya menuju pada perhatian kepada orang lain. Selanjutnya akan dimungkinkan terbentuk suatu tindakan moral yang memperhatikan nilai-nilai universal. Perilaku moral anak tidak hanya didasarkan pada pertimbangan suatu akibat(menguntungkan dan merugikan), yang memperhatikan aturan atau kesepakatan sosial dan nilai universal yang dijunjung dan mempunyai konsekuensi terhadap kehidupan masyarakat.

\section{Permasalahan Dalam Pendidikan Moral Di Sekolah}

Berpijak dari pembahasan di atas, maka permasalahan-permasalahan di sekolah, sehingga terjadi kesenjangan (moralitas), antara kondisi ideal output lembaga pendidikan dan kenyataan yang di jumpai, dan dianggap menyebabkan kurang optimalnya kualitas moral anak didik adalah:

1. Formulasi Pendidikan Moral dan Lemahnya Sistem Evaluasi Pendidikan Moral

Apabila dilihat dari pelaksanaan pendidikan moral di sekolah, maka akan diketahui bahwa penanaman dan pembentukan nilai-nilai moral cenderung dibekukan dalam suatu bentuk mata pelajaran, seperti pendidikan agama, PMP, atau Pancasila. Dalam mata pelajaran tersebut pendidikan moralnya pada tercapainya nilai lulus mata pelajaran dengan menekankan pada kemampuan anak didik tidak dapat diketahui dalam kondisi senyatanya. Bagaimanapun banyaknya nilai anak dalam menjawab soal-soal tentang pendidikan moral belum dapat dijamin tercapainya perkembangan moral yang baik sebab sebagaimana dikatakan Tilaar bahwa, "Untuk menilai perkembangan nilai moralitas anak didik, diperlukan penilaian terhadap realisasi 
perilaku moral anak dalam setiap lingkungan kehidupan anak. Akan tetapi, perilaku moral anak didik tidak tercakup dalam sistem evaluasi sekolah, bahkan tidak menjadi acuan dalam kelulusan". Dari hal tersebut dapat dipahami mengapa perkembangan moral anak tidak mencapai taraf moral yang baik. Hal ini dikarenakan perhatian anak tidak tertuju bagaimana merealisasikan nilai-nilai moral yang diajarkan dalam kehidupan nyata tetapi ia cenderung lebih konsentrasi pada penguasaan materi dan kemampuan menjawab soal-soal formal dalam ujian.

Di lain pihak, pendidikan moral yang seharusnya disampaikan secara inheren dalam seluruh mata pelajaran dikelas, ternyata tidak dilakukan. Dalam bidang studi-bidang studi yang lain bahkan acuh terhadap transformasi nilai moral pada anak didik. Mereka lebih mementingkan aspek pengetahuan bidang studi itu sendiri, bebas dari penyampaian nilai-nilai moral yang terkandung dalam materi yang diajarkan. Akibatnya perhatian terhadap pendidikan moral anak didik hanya dilakukan dalam mata pelajaran yang tertentu dan hal itupun tidak berjalan efektif(hanya difokuskan pada nilai kelulusan menjawab soal ujian), sehingga kualitas moral anak didik dalam realisasinya kurang mendapat perhatian maksimal. Oleh karena itu, kontrol, penilaian dan pengukuran perilaku moral anak didik tidak dapat diketahui, sampai tahap mana perkembangan moral anak didik telah dibentuk.

Upaya Pemecahan

Tujuan pendidikan dan pengajaran dapat dikatakan berhasil apabila anak mengalami proses perubahan. Perubahan itu tidak hanya parsial, namun totalitas. Artinya, perubahan tentang pendidikan moral belum menjamin tercapainya perkembangan moral yang baik. Evaluasi harus di kembangkan pada semua ranah dan harus dilakukan pada seluruh mata pelajaran. Maksudnya, keberhasilan pendidikan moral jangan dibebankan pada mata pelajaran pendidikan agama atau pendidikan moral saja, akan tetapi setiap mata pelajaran harus mempunyai hidden kurikulum(kurikulum tersimpan)yang disusun oleh guru masing-masing mata pelajaran. Setiap guru harus mempunyai misi untuk membantu anak didiknya mencapai moral yang sempurna dan jangan menganggap bahwa pendidikan moral itu hanya tugas guru agama saja. Perlu diketahui, selain mengajar, guru bidang mempunyai tugas memberikan informasi serentetan materi pelajaran, juga bertanggung jawab secara moral untuk membantu anak didik menjadi manusia yang sempurna baik jasmani maupun rohani, mampu berdiri sendiri memenuhi tugasnya sebagai mahluk tuhan, mahluk sosial dan sebagai individu yang mandiri (Yunus, 2000).

Dari uraian diatas, dapat disimpulkan bahwa tugas pendidik(orang tua, guru dan sebagainya), selain memberikan pengetahuan sebanyak-banyaknya, juga membantu anak menjadi anak yang bermoral sempurna. Adapun untuk mengetahui keberhasilan anak dalam belajar 
sehingga terbentuk moral yang baik dapat di identifikasikan dalam klasifikasinya Sujarwo dalam bukunya Beberapa Aspek Pengembangan Sumber Belajar, halaman 108-120, sebagai berikut:

a. Keberhasilan dalam kawasan kognitif (pengetahuan), apabila anak mempunyai kecakapan:

1) Kecakapan pengetahuan(knowledge), pengetahuan diartikan sebagai kemampuan seseorang dalam menghafal atau mengingat kembali atau mengulang kembali pengetahuan.

2) Kecakapan pengetahuan(comprehension), pemahaman diartikan sebagai kemampuan seseorang dalam mengartikan, menafsirkan, menerjemahkan atau menyatakan sesuatu dengan cara sendiri tentang pengetahuan yang telah diterimanya.

3) Kecakapan penerapan (application), penerapan diartikan sebagai kemampuan seseorang dalam menggunakan pengetahuan untuk memecahkan berbagai masalah yang timbul dalam kehidupan sehari-hari.

4) Kecakapan analisis (analysis), analisis diartikan sebagai kemampuan seseorang merinci dan membandingkan pengetahuan atau data yang begitu rumit, kemudian di klasifikasikan menjadi kategori dengan tujuan agar mengenal hubungan dan kedudukan masing-masing data terhadap data yang lain.

5) Kecakapan sintesis (synthesis), sintesis ini diartikan sebagai kemampuan seseorang dalam mengaitkan dan menyatukan berbagai elemen sehingga berbentuk pola baru yang lebih menyeluruh.

6) Kecakapan evaluasi (evaluation), evaluasi diartikan sebagai kemampuan seseorang membuat perkiraan atau keputusan yang tepat berdasarkan kriteria atau pengetahuan yang dimilikinya.

b. Keberhasilan dalam kawasan efektif (sikap dan perilaku), apabila anak memiliki kecakapan:

1) Menerima (receving), menerima dapat diartikan sebagai proses pembentukan sikap dan perilaku dengan cara membangkitkan kesadaran tentang adanya perangsang (stimulus) tertentu yang mengandung estetika.

2) Tanggapan (responding), tanggapan dapat disttikan sebagai kemampuan untuk bereaksi terhadap suatu kejadian (stimulus) dengan cara berpartisipasi dalam berbagai bentuk di terimanya sehingga sikap atau perbuatan itu seolah-olah telah menjadi ciri pribadinya.

3) Keberhasilan dalam kawasan psikomotorik, adalah kawasan yang berhubungan dengan koordinasi antara proses mental dan fisik dalam melakukan kegiatan atau gerakan yang bersifat jasmaniah. Dengan demikian, kawasan psikomotor adalah kawasan yang berhubungan dengan seluk beluk yang terjadi karena adanya koordinasi otot-otot oleh 
pikiran sehingga diperoleh tingkat keterampilan fisik tertentu. Misalnya keterampilan dalam membongkar dan memasang mesin, me-reparasi mesin dan sebagainya. Adapaun keterampilan psikomotor dibidang pendidikan moral adalah apabila anak tanpa disuruh(secara sadar)berlaku sopan kepada semua orang yang lebih tua atau muda, bicara sopan, peduli dengan sesama dan lain sebagainya.

2. Lemahnya Unsure Conditioning dalam Pendidikan Moral

Disamping hal diatas, permasalahan pendidikan moral disekolah adalah lemahnya unsure conditioning. Dari hal ini akan dapat dipahami mengapa terjadi kesenjangan (dalam moralitas) antara kondisi ideal output pendidikan dan kenyataan yang ada. Sebagaimana dijelaskan diatas, bahwa pendidikan moral berupaya untuk menanamkan dan membentuk perkembangan moral anak didik dalam tahap yang sempurna. Dalam proses tersebut dibutuhkan adanya pembiasan(conditioning)terhadap tahap prilaku moral yang diajarkan dengan memberikan hadiah, pujian, penghargaan prilaku moral yang baik, dan memberi hukuman perilaku moral yang tidak baik. Dengan adanya pembiasan tersebut anak akan dibiasakan melakukan perilaku moral yang baik dengan diberi reinforcement berupa hadiah, pujian atau hal lain yang menggembirakan anak, sehingga terjadi proses internalisasi nilai moral dalam diri anak. Jika pembiasan tersebut tidak berjalan dengan baik dalam diri anak didik. Akibatnya anak didik tidak dapat meng-integrasikan nilai moral dalam perilaku moral dalam kehidupannya.

Di sekolah, upaya pembiasaan dalam membentuk perilaku moral yang diharapkan kurang mendapat perhatian yang maksimal. Sebagai contoh kecil, dalam hal berdusta misalnya, pembiasaan berperilaku jujur, tidak bohong kurang mendapatkan perhatian yang serius. Guru bila menjumpai anak didik berbohong dalam suatu hal, ia cenderung menganggapnya sebagai hal yang wajar. Dalam artian tidak diberi reinforcement berupa hukuman yang keras agar anak tidak terbiasa melakukan perilaku dusta. Dari hal ini anak akan menangkap bahwa perilaku berbohong, tidak memberikan dampak yang sangat merugikan bagi dirinya, sehingga perhatian anak terhadap pembiasaan berprilaku jujur terabaikan.

Upaya Pemecahan

Untuk membentuk prilaku moral yang sempurna sesuai yang diharapkan, harus dimulai dari keluarga, karena keluarga adalah sebagai lembaga pertama dan orang tua sebagai pendidik primer/utama, oleh karena itu, orang sangat perlu menanamkan nilai-nilai positif kepada anak sejak dini sebagai bekalnya menyesuaikan diri terhadap lingkungannya. Jika anak sudah terbiasa melakukan perbuatan baik di rumah/di lingkungan keluarganya, maka kebiasaan-kebiasaan yang telah tertanam sejak dini akan mengikuti seterusnya pada perilaku anak di luar lingkungan keluarga misalnya di sekolah, di kantor, di lingkungan bermain dan sebagainya. 
Bagi orang yang sibuk berkarir, kadang-kadang salah mendefinisikan bahwa untuk menjadikan anak sukses harus disekolahkan di sekolah-sekolah favorit walaupun beresiko mendorong atau menstimulasi siswa terbiasa melakukan perilaku moral, yang baik dengan segala konsekuensinya, misalnya jika dia berbuat baik, diberi reward atau hadiah materi, akan tetapi biasa berupa pujian, penghargaan, pemberian tugas, justru anak akan bangga dan jika anak berbuat buruk maka anak diberi punishment(hukuman)yang setimpal dengan perbuatannya, baik ringan atau berat.

3. Kurang Mendukungnya Unsure Modeling dalam Pendidikan Moral

Sebagaimana dijelaskan di atas bahwa dalam proses pembentukan moral anak menuju ke tahap yang lebih tinggi(sempurna), adanya peniruan terhadap figur yang di idolakan, cenderung dilakukan anak didik. Ini berarti segala tindakan(perilaku moral) guru akan cenderung ditiru oleh murid yang mengidolakannya. Akibatnya, jika guru mampu menampilkan perilaku moral yang baik, maka anak didik akan cenderung meniru perilaku yang baik tersebut tersebut, atau bahkan cenderung menghilangkan peniruannya dalam perilaku moral yang baik dari guru tersebut. Dalam hal modeling ini, anak didik mempunyai berbagai tokoh idola, yakni orang tua, tokoh masyarakat bahkan kalangan selebritis. Semakin tinggi tingkat peng-idolaan anak terhadap suatu figur, maka semakin berpengaruh perilaku figur tersebut dalam diri anak melalui proses modeling tersebut. Padahal, berdasarkan pengamatan, banyak anak didik yang menjadikan para selebriti(artis, politis, birokasi)sebagai figur idola mereka. Ini berarti proses modeling terhadap perilaku moral figur tersebut sangat dominan dalam diri anak. Ini berarti perilaku moral yang baik dari guru sebagai teladan yang diberikan kepada anak didik dalam proses penanaman dan pengembangan moral mereka cenderung kurang mendapatkan respon positif.

Proses modeling terhadap perilaku moral baik tersebut tidak berjalan, dikalahkan oleh proses modeling dari tokoh lain, padahal para anak didik itu dalam perilaku mereka ditiru. Sehingga banyak perilaku moral yang tidak diharapkan ditampilakan. Sehingga akan terjadi pertentangan dalam proses modeling, dan ini kurang membantu terhadap perkembangan anak didik. Dalam hal bersikap jujur misalnya, jika tokoh selebriti dijumpai anak didik melakukan perilaku moral yang tidak baik(misalnya tidak jujur, berbohong atau menipu), dan itu membawa dampak yang merugikan, bahkan membawa yang menguntungkan, maka anak didik akan berada dalam konflik moral, dan juga cenderung meniru tindakan tidak jujur yang dicontohkan dari tokoh idolanya tersebut. Karena dipandang tidak mempunyai akibat yang merugikan bagi dirinya. Sebagaimana dalam tahap perkembangan moral pra-konvensional, sehingga anak 
selanjutnya akan cenderung bersifat hypocrite. Dari hal ini selanjutnya mengakibatkan proses pendidikan moral anak tidak berjalan dengan efektif.

Upaya Pemecahan

Suatu kenyataan bahwa tidak semua guru mencerminkan perilaku atau sikap moral yang baik. Banyak guru yang menampakkan keegoisannya, mungkin disebabkan faktor menjaga posisi jabatannya. Mereka lupa bahwa sosok seorang guru adalah orang yang secara sengaja maupun tidak sengaja, keseluruhan aspek kepribadiannya akan ditiru muridnya. Oleh karena itu proses modeling perlu dikondisikan baik melalui tata cara bicaranya, sikapnya, pendiriannya kedisiplinan ibadah shalatnya, dan lain sebagainya, baik berlaku untuk guru maupun murid.

4. Lemahnya Pembahasan Konflik Moral

Sebagaimana disebutkan di atas, bahwa anak sering berada dalam konflik moral. Yakni nilai moral yang diajarkan, ditanamkan di sekolah sering berbeda dengan situasi moral di masyarakat yang ditangkap anak didik. Akibatnya, seperti yang dikatakan oleh Kohlberg: “Anak berada dalam kondisi konflik moral yang membutuhkan pembahasan dan pemecahan yang arif, dalam proses pendidikan moral". Ini berarti apabila anak berada dalam konflik moral tersebut, khususnya dalam tahap pra-konvensional, maka perlu dilakukan pembahasan intensif tentang pertentangan antara alasan perilaku moral dan tindakan moral serta akibat dari tindakan moral yang bertentangan dengan kepentingan anak didik. Sebagaimana dalam contoh tentang bersikap jujur dalam contoh tersebut diatas.

Pelaksanaan pendidikan moral di sekolah kurang memberi ruang, adanya pembahasan konflik moral tersebut. Hal ini dikarenakan bentuk pengajarannya yang cenderung tekstual, dan tidak adanya umpan balik dari orang tua atau dari anak didik sendiri, tentang konflik moral yang di alaminya. Akibatnya, anak didik mencari perilaku moral menurut keuntungan yang diperoleh dirinya dengan perilaku moral tersebut. Walaupun perilaku moral tersebut, sebenarnya bukan perilaku moral yang diharapkan dalam pendidikan moral. Dalam pengambilan keputusan melakukan tindakan moral yang dalam suasana konflik moral tersebut, teman sebaya akan banyak memberi peran. Ini berarti jika anak hidup dalam lingkungan teman yang baik, maka ia akan cenderung memutuskan perilaku yang baik. Namun, jika ia berada dalam lingkungan teman yang tidak baik, maka ia akan cenderung melakukan keputusan terhadap perilaku moral yang tidak baik. Sehingga proses penanaman nilai moral di sekolah tidak dapat berjalan dengan baik. Dengan adanya pembicaraan intensif tentang konflik moral, maka guru akan dapat membimbing anak menentukan pilihan moral yang tepat, dan dapat membantu peningkatan tahap perkembangan moral anak didik, ke tahap yang lebih tinggi, yakni tahap pasca 
konvensional, tahap perkembangan moral yang mulai memperhatikan nilai-nilai universal. Akan tetapi hal ini sering tidak dilakukan dalam pendidikan moral di sekolah.

Upaya Pemecahan

Adanya ke-tidaksinkronan pembahasan moral yang diajarkan di sekolah dengan situasi moral di masyarakat, yang menganalisis kebaikan dan keburukannya, serta anak tidak melakukan atau berperilaku moral.

\section{Simpulan}

Sebagaimana telah disebutkan di atas, bahwa telah terjadi kesenjangan antara apa yang diharapkan dan apa yang terjadi dalam kenyataan perihal moralitas pelajar, sebagaimana apa yang dijelaskan oleh Tilaar. Dari itu perlu di identifikasi mengenai masalah dalam pendidikan moral di sekolah. Tabiat atau moral anak dapat dikembangkan kearah yang lebih sempurna. Upaya ini dapat ditempuh melalui proses pendidikan moral. Pendidikan moral tersebut berupaya membantu anak didik mencapai tahap perkembangan moral yang lebih sempurna. Dalam kerangka itu diperlukan adanya suatu proses yang terprogram. Proses penanaman dan pembinaan serta pengembangan anak didik di sekolah tersebut menempatkan unsur pembiasaan, peniruan dan pemberian contoh yang baik serta pemahaman terhadap pertimbangan dan perilaku moral. Adapun permasalahan yang terjadi dalam kehidupan moral di sekolah, setidaknya yang dapat di identifikasi adalah: adanya formalisasi pendidikan moral, lemahnya unsur pembiasaan dalam pendidikan moral, kurang mendukungnya unsur modeling dalam kehidupan moral, dan lemahnya pembahasan tentang konflik moral di sekolah.

\section{Daftar Pustaka}

Kohlberg dan Cande D.T.T. Relasi antara Pertimbangan Moral dengan Tindakan Moral. Wiliam Kurines. Moralitas. 84.

Langgulung, Hasan. (1982). Beberapa Pemikiran Tentang Pendidikan. Bandung: Al-Maarif.

M. Kurtines, Wiliam. (1992). Moralitas, Perilaku, dan Perkembangan Moral. Jakarta: UI

Marpinjun, Sri. (2000). Pola Asuh Orang Tua dan Komunikasi Efektif Orang Tua dan Anak.

Namsa, Yunus. (2000). Metodologi Pengajaran Agama Islam. Jakarta: Pustaka Firdaus.

Seifert, Alfin. (1983). Educational Psichology. New Jersey.

Soebagjo, Azima. (2000). Mewaspadai Dampak Media. Seminar Nasional.

Sujarwo, S. (1988). Beberapa Aspek Pengembangan Sumber Belajar. Jakarta: Mediyatama Sarana Perkasa.

Syah, Muhibbin. (1995). Psikolog Pendidikan. Bandung: Remaja Rosdakarya.

Tilaar, H.A.R. (1999). Agenda Reformasi Pendidikan Nasional. Magelang: Tera Indonesia. Yogyakarta: Seminar Nasional. 